\title{
Hypocalcaemic Primary Hyperparathyroidism
}

\author{
W. M. KEYNES,* M.D., M.CHIR., F.R.C.S.; F. I. CAIRD, † D.M., M.R.C.P.
}

\begin{abstract}
Summary: A patient with many symptoms and signs of primary hyperparathyroidism had hypocalcaemia when first seen. Bone section histology showed osteomalacia and osteitis fibrosa, and the hyperparathyroidism at this stage was considered to be secondary to osteomalacia with postgastrectomy steatorrhoea. On treatment with vitamin $D$ (with disappearance of her bone pains and weakness) she developed hypercalcaemia. She regained her health after removal of a 6-g. parathyroid adenoma. Normal histology was shown in another parathyroid gland.

We believe that the initial hypocalcaemia was due to vitamin-D deficiency, which produced ineffective hyperparathyroidism until it was corrected. A review of the few reports of patients with autonomous hyperparathyroidism with steatorrhoea and osteomalacia does not support the argument that these patients had "tertiary" disease. It suggests that most of them, like our patient, had primary hyperparathyroidism.
\end{abstract}

\section{Introduction}

With the suggestion of Davies et al. (1956) and Stanbury et al. (1960) that long-term stimulation of the parathyroids can occasionally lead from compensatory to autonomous hyperfunction with hypercalcaemia, St. Goar (Case Records, 1963) used the term "tertiary hyperparathyroidism" to denote the autonomous state which developed on a background of secondary hyperparathyroidism. Since then there have been several reports (Case Records, 1963; McPhaul et al., 1964; Golden et al., 1965; McIntosh et al., 1966) of tertiary hyperparathyroidism in patients with chronic renal disease. In secondary hyperparathyroidism all the parathyroid glands show histological hyperplasia, and in tertiary disease from renal insufficiency the enlarged glands have also shown the changes of chief-cell hyperplasia, with the addition of an adenoma in a few. It must be emphasized that with an adenoma the other parathyroid glands, when examined, have all shown hyperplasia (Roth, 1968), and it may be difficult to be sure that the adenoma was not primary with secondary hyperplasia in the other glands resulting from renal insufficiency. Otherwise in primary hyperparathyroidism due to a single adenoma the other parathyroid tissue should not show any hyperplastic change. "Primary" hyperparathyroidism is the cause of abnormal calcium metabolism, while "secondary" and "tertiary" hyperparathyroidism are a result of abnormal calcium metabolism (Lamki, 1969).

Secondary parathyroid hyperplasia occurs in osteomalacia, and it has been natural to postulate "tertiary" disease to explain autonomous hyperparathyroidism with hypercalcaemia in patients with steatorrhoea and osteomalacia. Analysis of reports of such "tertiary" disease (see Table), however, does not rule out primary disease in the majority. In this paper we report the case of a patient with hyperparathyroidism who when first seen was hypocalcaemic and showed the bone changes of osteomalacia. Others would possibly consider that she had ter-

\footnotetext{
* First Assistant, Nuffield Department of Surgery, Radcliffe Infirmary,
} Oxford.

† Medical Tutor, Nuffield Department of Medicine, Radcliffe Infirmary, Oxford. Present address : Department of Geriatric Medicine, Stobhill General Hospital, Glasgow N.1. tiary hyperparathyroidism, but we believe her primary disease was masked by vitamin-D deficiency, a state in which the action of parathyroid hormone may be blocked. Several patients with steatorrhoea and osteomalacia, and reported to have tertiary disease (see Table), have also shown rises in plasma calcium levels on being given vitamin-D leading to the diagnosis of hyperparathyroidism.

\section{Case History}

A 41-year-old housewife was referred in April 1963 by her general practitioner, Dr. J. Nickson, with hypocalcaemia, hypophosphataemia, and a raised plasma alkaline phosphatase. He suggested that her history of duodenal ulcer, limb pains, and depression might be due to hyperparathyroidism, but if so the hypocalcaemia was most surprising.

In 1949, at the age of 28, she developed dyspepsia, and in 1955 underwent a partial gastrectomy for duodenal ulcer. Her symptoms recurred, and in 1958 a vagotomy was performed because of a stomal ulcer. After this she lost her abdominal pain, but noticed the passage of pale stools. She became depressed and suicidal and so disabled by limb pains and weakness that her husband had to carry her upstairs. She noted increasing thirst and polyuria.

In March 1963 the plasma calcium was estimated for the first time and found to be $4.0 \mathrm{mEq} / 1$., with inorganic phosphate 1.4 mg./100 ml., and alkaline phosphatase $20 \mathrm{King}$-Armstrong units (see Chart). Further low plasma calcium levels were recorded, and

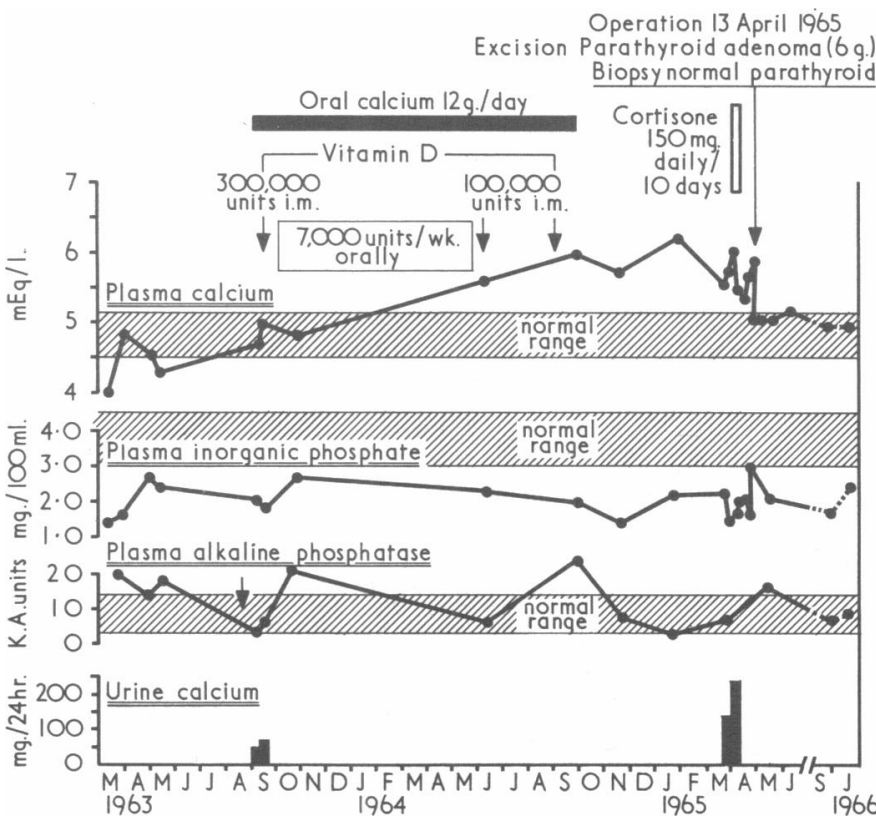

Plasma calcium, inorganic phosphate, and alkaline phosphatase levels over the months from 1963 to 1966. Initial hypocalcaemia changed to hypercalcaemia after treatment with vitamin $D$.

she was noted to be thin, pale, and depressed. There was diffuse bone tenderness, and skeletal $x$-ray examination showed diffuse demineralization of the bones with an osteolytic lesion in the right clavicle and subperiosteal erosions of the phalanges. A biopsy specimen from the iliac crest cut easily and was reported by Dr. W. C. D. Richards to show both osteomalacia and osteitis fibrosa. An intravenous pyelogram showed a calculus in the right kidney. The haemoglobin was $11.9 \mathrm{~g} . / 100 \mathrm{ml}$., and there was a macrocytic 
anaemia (which responded to iron, oral vitamins, and folic acid) with a steatorrhoea (without diarrhoea) of $12.6 \mathrm{~g}$. of faecal fat per 24 hours. The total plasma protein level was $6.0 \mathrm{~g} . / 100 \mathrm{ml}$., with albumin $4.1 \mathrm{~g} . / 100 \mathrm{ml}$. The blood urea was $24 \mathrm{mg} . / 100 \mathrm{ml}$., plasma electrolytes were normal, and after three days on an intake of $140 \mathrm{mg}$. of calcium a day the 24-hour urinary calcium excretion was 41 and $51 \mathrm{mg}$.

It was felt that the hypocalcaemia and hyperparathyroidism were secondary to postgastrectomy osteomalacia with steatorrhoea and deficient vitamin-D absorption, so she was treated with vitamin-D, one dose of 300,000 units intramuscularly, and then 7,000 units weekly by mouth, with oral calcium as well. The bone pain rapidly improved and her depression largely lifted. In June 1964 she was still somewhat depressed, and her plasma calcium level was raised at $5.7 \mathrm{mEq} / 1$., a rise which persisted despite stopping the vitamin-D and calcium. In March 1965, when there was no longer any bone tenderness or depression, a cortisone suppression test (Dent, 1956, 1962; Dent and Watson, 1968) failed to show reduction in the plasma calcium concentrations.

On exploration by one of us (W.M.K.) in April 1965 a tumour was found lying deep to the left inferior thyroid artery. Above this was a normal left upper parathyroid gland from which a biopsy specimen was taken. No parathyroid tissue was discovered on the right, but the search was not continued for long. The tumour weighed $6 \mathrm{~g}$., measured 4 by 1.5 by $1.5 \mathrm{~cm}$., and on histological examination by Dr. W. Aherne was seen to be a parathyroid adenoma. The other parathyroid was histologically normal with no hyperplasia (Roth, 1968). The postoperative course was uneventful, and 14 months later the plasma calcium was $5.1 \mathrm{mEq} / 1$, with a plasma inorganic phosphate level of $2.6 \mathrm{mg} . / 100 \mathrm{ml}$. She was well at this time and without depression, and $x$-ray films suggested healing of the osteolytic lesion seen in the right clavicle in 1963.

In 1968 a retrospective report on the 1963 bone sections by Dr. C. G. Woods stated: "Osteoid $31 \%$ of total matrix; 3-6 lamellae in osteoid seams; surface covered by osteoid $60 \%$ (method of Woods et al., 1968). There is extensive surface fibrosis and excessive os- teoclastic activity.... The amount of osteoid and width of the osteoid seams is smaller than I would expect in 'gastrointestinal' osteomalacia with secondary hyperparathyroidism, and the way in which the bone resorption is taking place is more like that of primary than secondary hyperparathyroidism."

\section{Discussion}

We have described the case of a patient who after partial gastrectomy and vagotomy for duodenal and stomal ulcer developed depression, bone pains, thirst, and polyuria, and in whom investigation then showed hypocalcaemia, hypophosphataemia, a raised alkaline phosphatase level, normal renal function, and steatorrhoea with a macrocytic anaemia. Radiographs showed a renal stone, diffuse osseous demineralization with a bone "cyst" and subperiosteal phalangeal erosions, and bone biopsy osteomalacia and osteitis fibrosa. A diagnosis was made of vitamin-D deficiency and secondary hyperparathyroidism, with the type of hyperparathyroidism resting on the finding of hypocalcaemia. Such a low plasma calcium level has rarely been reported before in primary hyperparathyroidism, so that diagnosis was hardly likely, though osteomalacia has been reported (Davies et al., 1956; Ball, 1963; Prineas et al., 1965; Stanbury, 1968). Boyce and Jowsey (1966) examined the bone histology of 13 patients with primary hyperparathyroidism and suggested that the increased width of osteoid was due to the low plasma phosphate levels resulting in a low value of the product of plasma calcium and phosphate concentrations, despite the rise in plasma calcium.

The most reliable indication of primary hyperparathyroidism is the repeated finding of a raised total plasma calcium level, and Dent (1962) considered that one quite normal value

Details of Cases Reported in the Literature

\begin{tabular}{|c|c|c|c|c|c|c|c|}
\hline Author(s) & $\begin{array}{l}\text { Sex } \\
\text { Age }\end{array}$ & $\begin{array}{l}\text { Parathyroid } \\
\text { Pathology }\end{array}$ & $\begin{array}{l}\text { Aetiological } \\
\text { Factor(?) }\end{array}$ & Bone Assessment & Plasma Calcium & Present Assessment & Comments \\
\hline Davies et al. (1956) & F37 & No operation & Steatorrhoea & $\begin{array}{l}\text { Osteomalacia } \\
\text { osteosclerosis, }\end{array}$ & $\begin{array}{l}\text { No raised level till given } \\
\text { vitamin D }\end{array}$ & Masked H.P.T. & No bone biopsy \\
\hline Prineas et al. (1965) & F37 & Single adenoma & $\begin{array}{l}\text { Renal tubular } \\
\text { acidosis }\end{array}$ & $\begin{array}{l}\text { Osteomalacia, } \\
\text { osteosclerosis, }\end{array}$ & $\begin{array}{l}\text { No raised level till given } \\
\text { vitamin D }\end{array}$ & Masked H.P.T. & \\
\hline Glanville and Bloom (1965) & M46 & $\begin{array}{l}2 \text { adenomas } \\
2 \text { normal P.T.s }\end{array}$ & $\begin{array}{l}\text { Vitamin-D-resistant } \\
\text { osteomalacia }\end{array}$ & $\begin{array}{l}\text { no osteitis } \\
\text { Osteomalacia, no } \\
\text { osteitis }\end{array}$ & $\begin{array}{l}\text { No raised level till given } \\
\text { vitamin D }\end{array}$ & & No bone biopsy \\
\hline Davies et al. (1968) & F65 & Single adenoma & $\begin{array}{l}\text { Post-P.G. } \\
\text { Porta }\end{array}$ & $\begin{array}{l}\text { Osteomalacia, no } \\
\text { osteitis }\end{array}$ & $\begin{array}{l}\text { No raised level till given } \\
\text { vitamin } D\end{array}$ & Masked H.P.T. & No steatorrhoea \\
\hline Davies et al. (1968) & F47 & Single adenoma & Steatorrhoea & $\begin{array}{l}\text { Osteomalacia, } \\
\text { osteitis }\end{array}$ & $\begin{array}{l}\text { No raised level till given } \\
\text { vitamin D }\end{array}$ & Masked H.P.T. & \\
\hline Davies et al. (1968) & F28 & Single adenoma & Steatorrhoea & $\begin{array}{l}\text { Osteomalacia, } \\
\text { osteitis }\end{array}$ & $\begin{array}{l}\text { No raised level till given } \\
\text { vitamin D }\end{array}$ & Masked H.P.T. & \\
\hline Nadarajah et al. (1969) & F78 & $\begin{array}{l}1 \text { adenoma. } \\
1 \mathrm{P} . \mathrm{T} \text {. with hyper- } \\
\text { plasia. } 1 \text { normal } \\
\text { P.T. seen. }\end{array}$ & Post-P.G. & $\begin{array}{l}\text { Osteomalacia, } \\
\text { osteitis }\end{array}$ & $\begin{array}{l}\text { No raised level till given } \\
\text { vitamin } D\end{array}$ & Masked H.P.T. & $\begin{array}{l}\text { Osteomalacia } \\
\text { cured with } \\
\text { vit. D }\end{array}$ \\
\hline Davies et al. (1968) & F59 & Single adenoma & Steatorrhoea & $\begin{array}{l}\text { No osteomalacia, } \\
\text { no osteitis }\end{array}$ & $\begin{array}{l}\text { Sl. raised level higher with } \\
\text { vitamin D }\end{array}$ & Partially masked H.P.T. & No bone biopsy \\
\hline Davies et al. (1968) & F67 & Single adenoma & Post-P.G. & $\begin{array}{l}\text { no osteitis } \\
\text { Osteomalacia, } \\
\text { osteitis }\end{array}$ & $\begin{array}{l}\text { S1. raised level higher with } \\
\text { vitamin D }\end{array}$ & Partially masked H.P.T. & No bone biopsy \\
\hline Davies et al. (1968) & F46 & Single adenoma & Steatorrhoea & $\begin{array}{l}\text { Osteomalacia, no } \\
\text { osteitis }\end{array}$ & $\begin{array}{l}\text { Raised level higher with } \\
\text { vitamin D }\end{array}$ & Partially masked H.P.T. & \\
\hline Davies et al. (1968) & F64 & Single adenoma & ?Steatorrhoea & $\begin{array}{l}\text { No osteomalacia, } \\
\text { osteitis }\end{array}$ & $\begin{array}{l}\text { Level raised when first } \\
\text { seen }\end{array}$ & ?Primary H.P.T. & No bone biopsy \\
\hline Davies et al. (1968) & F72 & Single adenoma & Post-P.G. & $\begin{array}{l}\text { Osteomalacia, no } \\
\text { osteitis }\end{array}$ & $\begin{array}{l}\text { Level raised when first } \\
\text { seen }\end{array}$ & Could be primary H.P.T. & \\
\hline Page (1954) & M56 & Single adenoma & Steatorrhoea & $\begin{array}{l}\text { Osteoporosis, Paget's } \\
\text { dis. of ilium }\end{array}$ & $\begin{array}{l}\text { Level raised when first } \\
\text { seen }\end{array}$ & Primary H.P.T. & \\
\hline Plough and Kyle (1957) & M37 & $\begin{array}{l}\text { Single adenoma. } \\
2 \text { normal P.T.s } \\
\text { seen }\end{array}$ & $\begin{array}{l}\text { Post-pancreatitis } \\
\text { steatorrhoea }\end{array}$ & $\begin{array}{l}\text { No osteomalacia, } \\
\text { osteitis }\end{array}$ & $\begin{array}{l}\text { Raised level } 8 \text { years after } \\
\text { pancreatitis }\end{array}$ & Primary H.P.T. & \\
\hline Ludwig et al. (1967) & F74 & $\begin{array}{l}\text { Single adenoma } \\
\text { with normal rim. } \\
1 \text { normal P.T. }\end{array}$ & $\begin{array}{l}\text { Low phosphate } \\
\text { intake } 6 \text { years be- } \\
\text { fore for } 1 \text { t years }\end{array}$ & $\begin{array}{l}\text { Osteomalacia, } \\
\text { osteitis }\end{array}$ & $\begin{array}{l}\text { Raised level } 4 \frac{1}{2} \text { years after } \\
\text { cure phosphate depletion }\end{array}$ & Primary H.P.T. & No bone biopsy \\
\hline Davies et al. (1956) & F41 & 2 adenomas. & Steatorrhoea & $\begin{array}{l}\text { Osteomalacia, } \\
\text { osteosclerosis, }\end{array}$ & $\begin{array}{l}\text { Raised level when first } \\
\text { seen }\end{array}$ & ?Primary H.P.T. & No bone biopsy \\
\hline Stanbury (1968) & F67 & Single adenoma & Rickets & $\begin{array}{l}\text { Osteitis } \\
\text { Osteomalacia, } \\
\text { osteitis }\end{array}$ & Raised level when first & Primary H.P.T. & No bone biopsy \\
\hline Stanbury (1968) & F57 & $\begin{array}{l}\text { Primary chief-cell } \\
\text { hyperplasia of all } \\
\text { glands }\end{array}$ & Post-P.G. & $\begin{array}{l}\text { Ostertis } \\
\text { Osteomalacia, } \\
\text { osteitis }\end{array}$ & $\begin{array}{l}\text { Raised level when first } \\
\text { seen }\end{array}$ & Primary H.P.T. & \\
\hline Stanbury (1968) & F73 & No operation & $\begin{array}{l}\text { Vitamin-D-deficient } \\
\text { diet }\end{array}$ & $\begin{array}{l}\text { Osteomalacia, } \\
\text { osteitis }\end{array}$ & $\begin{array}{l}\text { Gradually rising level to } \\
\text { sl. raised one }\end{array}$ & Primary H.P.T. & $\begin{array}{l}\text { Treatment with } \\
\text { calcium only }\end{array}$ \\
\hline Prineas et al. (1965) & F45 & No operation & Steatorrhoea & Osteomalacia, & Normal level-expected & ?Primary H.P.T. & \\
\hline Cotton et al. (1969) & F61 & $\begin{array}{l}\text { Single adenoma. } \\
1 \text { normal P.T. }\end{array}$ & Steatorrhoea & $\begin{array}{l}\text { Ostetis } \\
\text { Osteomalacia, } \\
\text { no osteitis }\end{array}$ & $\begin{array}{l}\text { to rise later } \\
\text { Raised level when first } \\
\text { seen }\end{array}$ & ?Primary H.P.T. & \\
\hline Present case & F41 & $\begin{array}{l}\text { Single adenoma. } \\
1 \text { normal P.T. }\end{array}$ & Post-P.G. & $\begin{array}{l}\text { Osteomalacia, } \\
\text { osteitis }\end{array}$ & $\begin{array}{l}\text { Low level became raised } \\
\text { on giving vitamin D }\end{array}$ & Primary H.P.T. & \\
\hline
\end{tabular}


for the total calcium obtained with impeccable technique made that diagnosis most unlikely. Fluctuations in plasma calcium levels are rarely large, but variations of 0.5 to 1 $\mathrm{mEq} / 1$ may occur over a period of weeks and months (Hodgkinson and Edwards, 1963), and such variations may lower the total calcium level into the normal range in patients with "borderline" hyperparathyroidism. There have been several reports of successful diagnosis in patients with repeatedly normal values for the plasma calcium (Mather, 1953; Bogdonoff et al., 1956; George et al., 1965; Wills et al., 1969), the reason for operating being mostly calcareous renal disease. Mixter et al. (1962) noted that patients with hyperparathyroidism complicated by acute pancreatitis may be normocalcaemic during an attack. Hypocalcaemia in primary hyperparathyroidism must be excessively rare.

Our patient developed hypercalcaemia after treatment with vitamin-D, and the hypercalcaemia persisted when the medication was stopped and a course of cortisone was given. Exploration of her neck revealed a fair-sized parathyroid adenoma, and a biopsy specimen from another gland was histologically normal without hyperplasia. After removal of the adenoma she regained her health with normocalcaemia and healing of the bone "cyst." As so often happens after surgery in hyperparathyroidism, the blood inorganic phosphate level remained lower than the normal range (Albright and Reifenstein, 1948; Harrison and Nordin, 1960).

\section{Osteomalacia and the Parathyroids}

The association of osteomalacia with steatorrhoea was first noted in modern times by Holst (1927), and the "classical" description was given by Bennett et al. (1932). Some patients have a normal plasma calcium with low phosphate and raised alkaline phosphatase, but others have hypocalcaemia as well. The urinary excretion of calcium is low, and there may be weakness and bone pains-findings that were present in our patient. Her bone pains disappeared when she was given vitamin-D, and Morgan et al. (1965) found that such osteomalacia after gastrectomy improved with only small doses of vitamin-D, suggesting a simple deficiency.

Albright et al. (1937, 1948) suggested secondary parathyroid overactivity as an explanation of the low plasma phosphate level in osteomalacia and failure of parathyroid response in those patients with hypocalcaemia. The latter might reflect the general impairment of endocrine function in steatorrhoea (Mickerson, 1960), though this could not then explain the low phosphate level. Davies et al. (1956), however, postulated that vitamin-D deficiency from malabsorption in steatorrhoea caused the hypophosphataemia directly by reduced tubular reabsorption of phosphate. The hypocalcaemia of osteomalacia is the result of vitamin-D deficiency and leads to parathyroid hyperplasia (Nordin, 1961). It is unlikely that it results from parathyroid insufficiency, in the ordinary sense of the word, as suggested by Albright, but it will be interesting to find out the plasma levels of parathyroid hormone in patients with steatorrhoea and osteomalacia.

\section{Parathyroid Function in Vitamin-D Deficiency}

The action of parathyroid hormone on bone requires the presence of minimal amounts of vitamin-D (Harrison et al., 1958; Rasmussen et al., 1963; Harrison and Harrison, 1964; Arnaud et al., 1966), and thyroparathyroidectomy or the administration of parathyroid hormone does not alter the plasma calcium level of vitamin-D-deficient rats (Morii and DeLuca, 1967). There is evidence that vitamin-D deficiency in man can render the plasma-calcium-raising action of parathyroid hormone ineffective. Jonxis (1961) noticed in a
vitamin-D-deficient child that parathyroid hormone did not raise the plasma calcium or lower the plasma phosphate. Steendijk (1964) reported a restoration of responsiveness after giving vitamin-D to children with nutritional rickets. Fourman and Haapanen (1964) attributed the lack of rise in plasma calcium on injection of parathyroid hormone in four patients with hypocalcaemic osteomalacia to a block to the action of the hormone, and also noticed that they behaved differently from patients with parathyroid insufficiency. Evanson (1966) infused patients with steatorrhoea complicated by hypocalcaemia with parathyroid hormone, and thought the reduced rise in plasma calcium was compatible with insensitivity of bone to parathyroid hormone, probably from vitamin-D deficiency. He also found that the lack of response could not be explained by secondary hyperparathyroidism. Bernstein et al. (1962) described how increasing doses of parathyroid hormone failed to raise the plasma calcium in a patient with hypocalcaemia, steatorrhoea, and hypoparathyroidism until the vitamin-D deficiency had been corrected.

We conclude that a block to the action of parathyroid hormone was present in our patient so long as she was vitamin$\mathrm{D}$ deficient. With administration of vitamin-D primary hypperparathyroidism was unmasked. Ten other cases are reported with steatorrhoea and osteomalacia in which the plasma calcium rose to diagnostic level on giving vitamin-D (see Table). We can also postulate that the hypocalcaemia sometimes seen in osteomalacia is due to vitamin-D deficiency without parathyroid insufficiency and to blocking of the action of parathyroid hormone. It is an expression of the degree of deficiency, or the degree of response of that person to the deficiency.

\section{Steatorrhoea, Osteomalacia, and Hyperparathyroidism}

Eighteen patients with osteomalacia and four others in whom the question of tertiary hyperparathyroidism not due to renal failure has been raised are reviewed in the Table. In eight the diagnosis of hyperparathyroidism resulted when hypercalcaemia followed vitamin-D medication, and in three more the hypercalcaemia on presentation became more pronounced on giving vitamin-D. These 11 patients may well have had primary hyperparathyroidism masked by vitamin-D deficiency. Seven patients had raised plasma calcium levels when tertiary hyperparathyroidism was first considered, and the development from secondary disease must be a matter of surmise. The histology of the other parathyroid glands in 12 patients in whom single adenomas were discovered is not known : there was no operation in three, and in six patients normal parathyroid tissue was described in addition to removal of parathyroid tumours. Six of the patients developed osteomalacia after an earlier partial gastrectomy, and in eight steatorrhoea was due to a probable gluten-induced enteropathy. In the 16 patients for whom tertiary hyperparathyroidism has been claimed (one had no operation and 15 had adenomas removed, with a suggestion of hyperplasia in one other parathyroid gland in only one) a diagnosis of primary hyperparathyroidism appears at least equally likely.

We can argue that our patient had primary hyperparathyroidism on several counts, with ineffective hyperparathyroidism while she was vitamin-D deficient. There was much evidence in favour of primary disease despite her hypocalcaemia, and she was apparently cured by removal of a fairsized (6-g.) parathyroid adenoma, with a biopsy specimen from another gland showing normal histology. We have already pointed out that in tertiary disease with an adenoma hyperplasia of the other parathyroids should be expected, though it is perhaps possible to argue that in our patient vitamin-D had been given long enough to lead to involution of any hyperplasia.

We are indebted to many colleagues for help in various aspects of this paper and wish to thank Dr. J. Nickson, who originally 
referred the patient here reported to Dr. J. Badenoch at the Radcliffe Infirmary, and also Drs. Richards, Aherne, and Woods for pathological reports quoted in the text. Among those who provided information and helpful discussion we mention with gratitude the late Professor P. Fourman, Dr. B. E. C. Nordin, Dr. C. G. Woods, Dr. S. I. Roth, and, most particularly, Professor S. W. Stanbury and Dr. J. T. Potts jun.

\section{REFERENCES}

Albright, F., Butler, A. M., and Bloomberg, E. (1937). American foumal of Diseases of Childhood, 54, 529.

Albright, F., and Reifenstein, E. C., jun. (1948). The Parathyroid Glands and Metabolic Bone Disease. Baltimore, Williams \& Wilkins.

Arnaud, C., Rasmussen, H., and Anast, C. (1966). Fournal of Clinical Investigation, 45, 1955.

Ball, J. (1963). In Bone Metabolism in Relation to Clinical Medicine, edited by H. A. Sissons, p. 31. London, Pitman Medical.

Bennett, T. I., Hunter, D., and Vaughan, J. M. (1932). Quarterly foumal of Medicine, 1, 603.

Bernstein, D., Kleeman, C. R., Dowling, J. T., and Maxwell, M. H. (1962). Archives of Internal Medicine, 109, 43.

Bogdonoff, M. D., Woods, A. H., White, J. E., and Engel, F. L. (1956). American fournal of Medicine, 21, 583.

Boyce, D., and Jowsey, J. (1966) Proceedings of the Staff Meetings of the Mayo Clinic, 41. 836.

Case Records of the Massachusetts General Hospital (1963). New England Fournal of Medicine, 268, 943.

Cotton, S. G., Bloom, A., and Dent, C. E. (1969). Proceedings of the Royal Society of Medicine, 62, 737.

Davies, D. R., Dent, C. E., and Watson, L. (1968). British Medical fournal, 3, 395.

Davies, D. R., Dent, C. E., and Willcox, A. (1956). British Medical Fournal, 2, 1133.

Dent, C. E. (1956). British Medical fournal, 1, 230.

Dent, C. E. (1962). British Medical fournal, 2, 1419, 1425.

Dent, C. E., and Watson, L. (1968). Lancet, 2, 662.

Evanson, J. M. (1966). Clinical Science, 31, 63.

Fourman, P., and Haapanen, E. (1964). Schweizerische Medizinische Wochenschrift, 94, 886

George, J. M., Rabson, A. S., Ketcham, A., and Bartter, F C. (1965).

Quarterly fournal of Medicine, 34, 291.
Glanville, H. J., and Bloom, R. (1965). British Medical fournal, 2, 26.
Golden, A., Canary, J. J., and Kerwin, D. M. (1965). American fournal of Medicine, 38, 562 .

Harrison, H. E., and Harrison, H. C. (1964). Metabolism, 13, 952.

Harrison, H. C., Harrison, H. E., and Park, E. A. (1958). American Fournal of Physiology, 192, 432.

Harrison, M., and Nordin, B. E. C. (1960). British Medical fournal, 1, 245.

Hodgkinson, A., and Edwards, N. A. (1963). British fournal of Urology, $35,445$.

Holst, J. E. (1927). Acta Medica Scandinavica, 66, 74.

Jonxis, J. H. P. (1961). Fournal of Pediatrics, 59, 607

Lamki, L. (1969). Lancet, 1, 888.

Ludwig, G. D., Kyle, G. C., and de Blanco, M. (1967). American fournal of Medicine, 43, 136.

McIntosh D. A., Peterson, E. W., and McPhaul, J. J., jun. (1966) Annals of Internal Medicine, 65, 900 .

McPhaul, J. J., jun., McIntosh, D. A., Hammond, W. S., and Park, O. K. (1964). New England Fournal of Medicine, 271, 1342.

Mather, H. G. (1953). British Medical Fournal, 2, 424.

Mickerson, J. N. (1960). British Medical fournal, 1, 529.

Mixter, C. G., jun., Keynes, M., and Cope, O. (1962). New England fournal of Medicine, 266, 265.

Morgan, D. B., Paterson, C. R., Woods, C. G., Pulvertaft, C. N., and Fourman, P. (1965). Lancet, 2, 1089.

Morii, H., and DeLuca, H. F. (1967). American fournal of Physiology, $213,358$.

Nadarajah, A., Joplin, G. F., Taylor, S., and Williams, E. D. (1969). Proceedings of the Royal Society of Medicine, 62, 709.

Nordin. B. E. C. (1961). Advances in Clinical Chemistry, 4, 275

Page, F. (1954). Archives of the Middlesex Hospital, 4, 215.

Plough, I. C., and Kyle, L. H. (1957). Annals of Internal Medicine, 47, 590.

Prineas, J. W., Mason, A. S., and Henson, R. A. (1965). British Medical fournal, 1, 1034.

Rasmussen, H., DeLuca, H. F., Arnaud, C., Hawker, C., and von Stedingk, M. (1963). Fournal of Clinical Investigation, 42, 1940.

Roth, S. I. (1968). Personal communication.

Stanbury, S. W. (1968) Personal communication.

Stanbury, S. W., Lumb, G. A., and Nicholson, W. F. (1960). Lancet, 1, 793.

Steendijk, R. (1964). Acta Paediatrica, 53, 105.

Wills, M. R., Pak, C. Y. C., Hammond, W. G., and Bartter, F. C. (1969). American fournal of Medicine, 47, 384.

Woods, C. G., Morgan, D. B., Paterson, C. R., and Gossman, H. H. (1968). Fournal of Pathology and Bacteriology, 95, 441.

\title{
Enuresis and the Electric Alarm: Study of 200 Cases
}

\author{
W. I. FORSYTHE, ${ }^{*}$ M.D., F.R.C.P.ED.; A. REDMOND, † M.R.C.P.I.
}

\begin{abstract}
Qummary: Of 200 children with persistent enuresis $66 \%$ were cured after treatment with an electric alarm over a 30-week period. It is suggested that treatment may be discontinued after the child has been dry for four weeks, that if continued for longer than 16 weeks treatment is unlikely to produce a cure, and that a two-year follow-up period is necessary before a cure can be accepted.
\end{abstract}

\section{Introduction}

Nocturnal enuresis may be defined as urinary incontinence occurring during sleep in children aged 3 years or older in the absence of congenital or acquired defects of the central nervous or genitourinary tract. It is one of the most common and harassing conditions in childhood. Not only does it require patience on the part of the doctor treating the child but the whole family may be involved. The patient as he grows older realizes that he is different and finds that he is unable to take part in activities which necessitate staying away from home -for example, camping, etc. The mother in her anxiety and

* Consultant Paediatrician.

†Senior Registrar. The Enuretic Clinic, The Royal Belfast Hospital for Sick Children,
Belfast BT12 6BE. resentment has difficulty in not transferring her despair to the child after nights of changing and days of washing bedclothes. In Britain during the second world war people's attitude towards enuresis changed. With the mass evacuation of children to urban areas it was realized that enuresis was much more common than previously suspected. Emotional stress was advanced as a major cause, and this resulted in the introduction of psychotherapeutic methods of treatment followed later by drugs and conditioning methods.

Drug therapy has not proved successful, and the results from it are not as good as those obtained with conditioning methods. Young (1965) had a cure rate of 36\% with drugs; he found that it took twice as long to obtain a cure and that relapse was twice as common as with conditioning methods. The results with the latter have been most encouraging and can explain the increased enthusiasm for this treatment. It is, however, difficult to subject the method to a controlled trial. Kahane (1955), attempted to do this by comparing patients treated by means of an electric alarm with those on the waiting-list and found little difference between the groups. Forrester, Stein, and Susser (1964) carried out a controlled trial with the alarm and with amphetamine; they found that amphetamine did not accelerate cure and that the alarm was more effective. 